\title{
26. Jahrestagung der FG "Innere Medizin und klinische Labordiagnostik" der DVG (InnLab), 02./03. Februar 2018 in Hannover - Teil 1
}

\section{Vorträge}

V01 Probiotikatherapie bei Hunden mit akutem hämorrhagischem Diarrhö-Syndrom (AHDS) - eine prospektive, plazebokontrollierte, geblindete Studie

A. L. Ziese ${ }^{1}$, J. S. Suchodolski ${ }^{2}$, F. Sarwar ${ }^{2}$, A. Anderson ${ }^{1}$, N. Sindern ${ }^{1}$, S. Unterer ${ }^{1}$

${ }^{1}$ Medizinische Kleintierklinik, Ludwig-Maximilians-Universität München; ${ }^{2}$ Gastrointestinal Laboratory, Department of Small Animal Clinical Sciences, Texas A\&M University, USA

Einleitung: Es ist bekannt, dass Clostridium (C.) perfringens und dessen Toxine eine Rolle in der Pathogenese des AHDS spielen und betroffene Hunde Veränderungen der intestinalen Mikrobiota aufweisen. Derzeit wird AHDS symptomatisch therapiert, wobei der Einfluss von Probiotika auf das intestinale Mikrobiom sowie den klinischen Verlauf bei Hunden mit AHDS bisher nicht untersucht wurde. Material und Methoden: 25 Hunde mit akutem hämorrhagischem Durchfall unbekannter Genese, ohne Anzeichen einer Sepsis, wurden in die Studie eingeschlossen und randomisiert einer Plazebo- $(\mathrm{PZ}, \mathrm{n}=12)$ oder einer Probiotikagruppe (PRO, $\mathrm{n}=13$, Vivomixx ${ }^{\oplus}$, MENDES S. A.) zugeteilt. Probiotikum/Plazebo wurden über 21 Tage oral verabreicht. C. perfringens gesamt und für NetF-Toxin sowie Enterotoxin kodierende C.-perfringens-Stämme wurden mittels quantitativer PCR aus Kotproben von Tag 0, 3, 7, 14, 21, 90 untersucht. Der klinische Verlauf wurde über 10 Tage ausgewertet. Ergebnisse: Die Menge an C. perfringens sank in Gruppe PRO von Tag 0 auf Tag 3 signifikant $(\mathrm{p}=0,032)$, während sie in Gruppe PZ zu keinem Zeitpunkt signifikant abfiel. Enterotoxigene C.-perfringens-Stämme waren in Gruppe PRO signifikant geringer vertreten als in Gruppe PZ an Tag $21(\mathrm{p}=0,028)$ und $90(\mathrm{p}=0,028)$. An Tag 0 waren $52 \%$ der Hunde positiv für NetF-Toxin-Gene; diese sanken in Gruppe PRO $(\mathrm{p}=0,016)$ und Gruppe PZ $(\mathrm{p}=0,031)$ signifikant von Tag 0 auf Tag 3. In beiden Gruppen zeigte sich eine rapide klinische Besserung ohne signifikanten Unterschied hinsichtlich des klinischen Verlaufs zwischen den Gruppen. Schlussfolgerung: Das verwendete Probiotikum führte zu einer beschleunigten Reduktion der Menge an C. perfringens. Unabhängig von der Probiotikatherapie zeigten alle Probanden in Gruppe PRO und PZ eine schnelle klinische Besserung.

V02 Untersuchung zum Verlauf des symmetrischen Dimethylarginins bei chronischen Nierenerkrankungen (IRIS Stage 1) geriatrischer Hunde nach Fütterung einer renoprotektiven Diät

\section{G. Sehn, A. Anders, N. Schulze, J.-P. Bach, I. Nolte}

Klinik für Kleintiere, Stiftung Tierärztliche Hochschule Hannover

Ziel der Studie ist, die Auswirkung eines renoprotektiven Futters auf den Verlauf einer chronischen Nierenerkrankung im frühen Stadium (IRIS Stage 1) bei älteren Hunden (> 7 Jahre) zu untersuchen. Das verwendete Futter zeichnet sich durch einen geringen Protein-, Phosphor- und Natriumgehalt sowie eine Anreicherung mit Omega-3-Fettsäuren, L-Carnitin und Beta-Carotin aus. Es wird labordiagnostisch die Nierenfunktion überprüft und über Laufbandanalysen die orthopädische Gesundheit untersucht. Methoden: Die Hunde ( $\mathrm{n}=13$ zum Zeitpunkt der Abstract-Einreichung) wurden randomisiert in eine Test- (Nierendiät Hill's k/d mobility) und eine Kontrollgruppe (Senior-Diät Hill's Science Plan Active Longevity) unterteilt. Um die Verblindung der Studie zu gewährleisten, wurden die Futtersorten als Futter A oder Futter B bezeichnet. Zu Beginn der Studie sowie nach 3, 6, 9 und 12 Monaten wird bei allen Patienten eine klinische Untersuchung, eine Blutuntersuchung, inklusive der Messung des symmetrischen Dimethylarginins (SDMA), und eine Urinuntersuchung durchgeführt. Bei den Kontrollen nach 6 und 12 Monaten erfolgen zusätzlich eine sonographische Untersuchung des Harntrakts und eine Laufbanduntersuchung. Zu jedem Termin wird das Befinden der Patienten von den Besitzern mittels eines Fragebogens bewertet. Bei einem Teil der Hunde erfolgt zusätzliche eine Bestimmung der glomerulären Filtrationsrate mittels Serum-Kreatinin-Clearance. Ergebnisse und Schlussfolgerung: Die bisherigen Untersuchungen zeigen weder bezüglich der Höhe der klassischen Nierenparameter oder des SDMAs noch bei der Besitzerbefragung einen deutlichen Unterschied in Bezug zu der Diät. Da sich die Studie zum Zeitpunkt der Abstract-Einreichung noch in einem frühen Stadium befand, kann noch keine endgültige Aussage zu den Auswirkungen der Fütterung des renoprotektiven Futters getroffen werden.

\section{V03 Reproduzierbarkeit von Holter-EKGs bei Dobermännern}

\section{S. Hauschild, G. Wess}

Medizinische Kleintierklinik, Ludwig-Maximilians-Universität München Abstract nicht verfügbar.

V04 Complications and short-term survival in end-stage tracheal collapse dogs treated with intraluminal selfexpanding wallstents

Y. Cui, M. Schneider, N. Hildebrandt, E. Hassdenteufel, N. Bauer, A. Moritz Klinik für Kleintiere, Innere Medizin, Justus-Liebig-Universität Gießen

Goals: The purpose of the retrospective study was to 1) report stent-related complications and 2) to evaluate the short-term clinical response of dogs with end-stage tracheal collapse treated with intraluminal stents. Method: Medical records of dogs with severe tracheal collapse, treated with intraluminal tracheal stents between 1 January 2006 and 31 December 2016 were reviewed. Inclusion criterion was refractory tracheal collapse with history of acute or progressive dyspnoea. Self-expanding stainless steel wallstents with a diameter of at least $1 \mathrm{~mm}$ larger than the laryngeal diameter were chosen. Clinical outcome was assessed at clinical check-up or by phone. The ideal follow-up protocol consisted of physical examination, blood work, chest radiographs and endoscopic re-evaluation. Results: Thirty-seven dogs were included, the most common breed was Yorkshire Terrier $(n=26)$. Twenty dogs were male ( 13 castrated) and 17 female (six castrated). The median age was 7.5 years (range 2-12 years). During the stenting procedure, two dogs suffered a fatal cardiac-pulmonary arrest. Five dogs died during the poststenting hospitalization period, of which four succumbed to aspiration pneumonia and one developed an acute kidney injury. During the 4-weeks post-stenting period two dogs developed dyspnoea again and were euthanized. The remaining 28 dogs showed partial or complete clinical improvement in breathing post-stenting. Check-up thoracic radiography was performed in 23 dogs. Nine dogs showed stent shortening, six without and three with clinical complaints. Endoscopy was done in 18 dogs. Eight patients showed mucosal pockets with mucus accumulation. Tracheitis was noted in 16 dogs of which 11 were confirmed to be of septic nature. Granulation tissue formations were reported in 13 cases of which nine were cli- 
nically relevant. Conclusion: This minimal invasive method of stabilizing the collapsed trachea is a valid alternative to surgery and provides almost immediate relief of the respiratory distress. Regular check-ups should be advised to owners to re-evaluate the clinical symptoms, since they often forebode stent-related complications.

V05 Vergleich von High-Definition-Oszillometrie (HDO) und konventioneller Oszillometrie (petMAP) mit direkt gemessenem arteriellem Blutdruck (ABD) bei verschiedenen Blutdruckzuständen bei wachen und anästhetisierten Hunden

\section{H. Piel, S. B. R. Kästner, T. Amon, J. Tünsmeyer}

Klinik für Kleintiere, Stiftung Tierärztliche Hochschule Hannover

Studienziel: Die Übereinstimmung zweier nichtinvasiver Blutdruckmessgeräte mit direkt gemessenem ABD bei normotensiven, hypotensiven und hypertensiven wachen und anästhesierten Hunden wurde untersucht. Methoden: In einer randomisierten, kompletten Cross-over-Studie wurde der ABD bei sieben Beagles gemessen. Für oszillometrische Messungen mittels petMAP- und HDO-Gerät wurden die Manschetten um Vordergliedmaße, Hintergliedmaße oder Schwanzbasis randomisiert platziert. Daten wurden mit invasiven Messungen an der dorsalen Metatarsalarterie verglichen. Zur Induktion von Hypertension (mittlerer arterieller Druck [MAD] $>120 \mathrm{mmHg}$ ) oder Hypotension (MAD $<60 \mathrm{mmHg}$ ) wurde Dopamin (10-18 $\mu \mathrm{g} / \mathrm{kg} /$ Minute i. v.) infundiert bzw. die inspiratorische Sevoflurankonzentration erhöht. Korrespondierender Herzauswurf wurde mittels Thermodilution bestimmt und systemischer Gefäßwiderstand (SVR) berechnet. Die Untersuchung der Übereinstimmung nichtinvasiver mit invasiven Messungen in unterschiedlichen Blutdruck- und SVR-Bereichen erfolgte mittels Bland-Altman-Analyse. Ergebnisse: Von 756 Messversuchen wurden insgesamt 752 bzw. 640 gepaarte Messungen für HDO- und petMAP-Gerät erhoben. Hoher SVR beeinträchtigte die Übereinstimmung beider Geräte mit ABD. Zur Übereinstimmung verschiedener MAD-Bereiche siehe Tab. 1. Schlussfolgerung: Das HDO-Gerät erzielte bei Hypo- und Normotension eine gute Übereinstimmung, während es bei Hypertension den $\mathrm{ABD}$ erheblich unterschätzte. Das petMAP-Gerät überschätzte den $\mathrm{ABD}$, vor allem bei normo- und hypertensiven Zuständen.

V06 Optimierung eines Scores zur zytologischen Leberzellbeurteilung beim Hund

\section{J. Aschenbruck, R. Mischke}

Klinik für Kleintiere der Stiftung Tierärztliche Hochschule Hannover

Einleitung: In der Tiermedizin wird die zytologische Untersuchung von Feinnadelpunktaten der Leber immer häufiger genutzt. Nur selten finden jedoch für die Beurteilung objektive Zell- und Kernkriterien Anwendung. Ziel dieser Studie war, ausgewählte Zell- und Kernkriterien anhand verschiedener Hepatopathien miteinander zu vergleichen und ein optimiertes

Tab. V05 Bias, Standardabweichung (SD) und Limits of Agreement (LoA) bei unterschiedlichen MAD-Bereichen

\begin{tabular}{|c|c|c|c|c|}
\hline & Bias \pm SD & LoA & MAD & n \\
\hline \multirow[t]{3}{*}{ HDO } & $-1,0 \pm 7,8$ & 14 bis -16 & Hypotension & 116 \\
\hline & $-8,3 \pm 11,8$ & 15 bis -31 & Normotension & 559 \\
\hline & $-19,5 \pm 19,5$ & 19 bis -58 & Hypertension & 77 \\
\hline \multirow[t]{3}{*}{ petMAP } & $4,3 \pm 8,3$ & 20 bis -12 & Hypotension & 110 \\
\hline & $5,4 \pm 16,6$ & 38 bis -27 & Normotension & 471 \\
\hline & $1,3 \pm 16,8$ & 34 bis -32 & Hypertension & 59 \\
\hline
\end{tabular}

Score-System zur Beurteilung von Leberzellen zu entwickeln. Material und Methoden: Es wurden zytologische Leberpräparate (v. a. Feinnadelaspirate) von jeweils fünf Hunden untersucht: glukokortikoidinduzierte Hepatopathie, Hepatitis, hepatozelluläres Karzinom, Lymphom mit Leberbeteiligung, histiozytäres Sarkom mit Leberbeteiligung, Kontrollhunde (fünf klinisch unauffällige Beagles). Untersucht wurden folgende Kriterien: zweikernige Zellen, multinukleäre Zellen, Chromatinverteilung, freiliegende Nuklei, intrazytoplasmatische Einschlüsse und Pigment und das Nukleus-Zytoplasma-Diameter-Verhältnis (N-Z-D-Verhältnis). Für die statistische Auswertung fanden Kruskal-Wallis-Test, Mann-Whitney-U- und Chi-QuadratTest Anwendung. Ergebnisse: Ein signifikant erhöhtes N-Z-D-Verhältnis bei hepatozellulärem Karzinom konnte sowohl bei subjektiver Schätzung als auch bei genauer Messung von 100 Leberzellen festgestellt werden. Mit letztgenannter Methode zeigte sich unter anderem auch ein vermindertes Verhältnis bei glukokortikoidinduzierter Hepatopathie. Im Vergleich zur Kontrollgruppe konnte ein deutlich höheres Vorkommen von multinukleären Zellen beim hepatozellulären Karzinom nur dann erfasst werden, wenn diese Zellen pro Gesichtsfeld gezählt wurden. Die Beurteilung von qualitativen Chromatinveränderungen in 100 Zellen pro Probe ergab eine signifikante Häufung von irregulären Chromatinverteilungen bei der Gruppe mit hepatozellulärem Karzinom im Vergleich zur Kontrollgruppe. Schlussfolgerung: Die Ergebnisse deuten an, dass das verwendete Beurteilungssystem einen deutlichen Einfluss auf die Aussage der Ergebnisse hat und bevorzugt quantitative Auswertungen eingesetzt werden sollten. Allein die Beurteilung der Anwesenheit von irregulärem Chromatin oder multinukleären Zellen ist nicht ausreichend für die Diagnose eines malignen Geschehens.

\section{V07 Rheologische Eigenschaften von Synovia als Basis rationaler Therapie}

\section{Wolf' ${ }^{1}$, N. Bauer ${ }^{1}$, C. Feichtenschlager ${ }^{2}$, E. K. Reichel ${ }^{3}$, A. Moritz ${ }^{1}$}

Klinikum Veterinärmedizin, ${ }^{1}$ Klinische Pathophysiologie \& Klinische Laboratoriumsdiagnostik, ${ }^{2}$ Klinik für Kleintiere (Chirurgie), Justus-Liebig-Universität Gießen, ${ }^{3}$ Institut für Mikroelektronik \& Mikrosensorik, Johannes-Kepler-

Universität Linz, Österreich

Der „Fadentest“ ermöglicht eine manuelle, semiquantitative Evaluation der Viskosität von Synovia und unterstützt somit die Diagnose einer Arthropathie. Das Fadenabriss-Dehnrheometer HAAKE CaBER1 ${ }^{\text {mx }}$ (Thermo Scientific) erlaubt mittels Messung der Abrisszeit („cutoff“) eine automatisierte Ermittlung der Viskosität von Flüssigkeiten und wurde bisher noch nicht für Synovia evaluiert. Ziel dieser prospektiven Studie war daher die quantitative, automatisierte Bestimmung der rheologischen und viskolelastischen Eigenschaften von Synovia beim Hund, die mithilfe des CaBER $1^{\text {Tw }}$ durchgeführt wurde. Zudem war die Untersuchung des Variationskoeffizienten der automatischen Messung im Vergleich zum manuellen Fadentest von Interesse. Material und Methoden: Von Mai 2016 bis Juli 2017 wurde Synovia aus 76 Gelenken von 55 Hunden mit dem CaBER $1^{\text {sx }}$ untersucht. Das Funktionsprinzip des CaBER1 ${ }^{\text {tw }}$ beruht auf der Verjüngung des Synoviafadens in Abhängigkeit von der Zeit. Einschlusskriterium für die Studie war ein ausreichendes Probenvolumen. Nach der Routinediagnostik wurden die Patientenproben anhand der Ergebnisse der zytologischen Untersuchung einer von drei Gruppen zugeteilt (Gruppe $1[\mathrm{n}=33]$ : degenerativ verändert, Gruppe $2[n=7]$ : gering- bis mittelgradig purulent, Gruppe $3[n=8]$ : hochgradig purulent) und mit der Kontrollgruppe (postmortal punktierte gesunde Gelenke, $n=18$ ) verglichen. Ergebnisse: Der mediane „cutoff“ war im Vergleich zur Kontrollgruppe (1,8; Range 0,9-2,9 s) signifikant kürzer $(\mathrm{p}<0,0001)$ in den Gruppen 2 (0,7; Range $0,1-1,9 \mathrm{~s})$ und 3 (0,2; Range 0,1-0,7 s), ebenso im Vergleich der Gruppen 1 (1,4; Range 0,2-2,5 s) und 3. Die Variationskoeffizienten für den Fadentest bzw. die automatisierten Messungen mittels CaBER ${ }^{\text {th }}$ betrugen $22 \%$ bzw. $5 \%$. Schlussfolgerung: 
Der CaBER1 ${ }^{\text {th }}$ erlaubt eine automatisierte, präzise Messung der Viskosität von Synovia und stellt somit ein standardisiertes Verfahren zur Erkennung einer Arthropathie dar.

\section{V08 In vitro Prüfung verschiedener Silikone auf Eignung als Implantatmaterial}

\section{Windhövel ${ }^{1}$, L. Harder ${ }^{1}$, M. Teske ${ }^{2}$, N. Grabow ${ }^{2}$, T. Eickner ${ }^{2}$, U. Hinze ${ }^{3}$,} I. Nolte ${ }^{1}$

${ }^{1}$ Klinik für Kleintiere, Tierärztliche Hochschule Hannover, Hannover; ${ }^{2}$ Institut für Biomedizinische Technik, Universitätsmedizin Rostock, Rostock; ${ }^{3}$ Laser Zentrum Hannover e. V., Hannover

Einleitung: Silikone werden in verschiedenen Indikationen in der Medizin als Implantat angewendet und haben dadurch Kontakt zu unterschiedlichen Geweben. In dieser Studie wurde das Wachstumsverhalten von humanen Sklera- (hSF) und humanen Tenonfibroblasten (hTF) auf sechs unterschiedlichen medizinisch zugelassenen Silikonen in vitro auf ihre zellabweisende Wirkung untersucht. Methoden: Zur Charakterisierung der Silikone wurden Kontaktwinkelmessung mit Wasser und Environmental-Scanning-Electron-Microscope(ESEM)-Aufnahmen der Oberfläche durchgeführt. Die im Zellversuch mit hSF und hTF besiedelten Silikone wurden nach 48 Stunden im Durchflusszytometer ausgewertet und mit einer Kontrolle auf Wellboden verglichen. $\mathrm{Zu}$ den Untersuchungsparametern gehörten die relative Zellzahl, der mithilfe des CellTrace-CFSE-Cell-Proliferation-Kit ermittelte Proliferationsindex und die durch TO-PRO ${ }^{\circledR}$-3-Aufnahme bestimmte Zellvitalität. Im Live Cell Imaging (LCI) wurden die CMFDA-gefärbten Zellen über 72 Stunden beobachtet. Ergebnisse: Alle Silikone zeigten gleichmäßig ebene Oberflächen mit Kontaktwinkeln über $100^{\circ}$. Die Zelldichte auf den Silikonen vergleichend zum Wellboden war signifikant reduziert. Weniger stark von den Silikonen beeinflusst waren die Proliferationsindizes. Die Vitalität der Zellpopulationen lag auf den Silikonen über $80 \%$. Im LCI zeigten beide Zelllinien ein schnelles und gleichmäßiges Anheften der Zellen auf dem Wellboden, während die Zellen auf den Silikonen über den gesamten Beobachtungszeitrum eine kugelige Form aufwiesen und sich traubenförmig zusammenlagerten. Schlussfolgerung: Aufgrund der hydrophoben Oberfläche kommt es zu einer deutlich reduzierten Anheftung von hSF und hTF auf den Silikonen. Die Proliferation wie auch die Vitalität ist hingegen nur gering reduziert. Eine Zellvitalität von über $80 \%$ war bei medizinisch zugelassenen Silikonen zu erwarten. Die unterschiedlichen Silikone haben ähnliche zellabweisende Eigenschaften.

\section{V09 Splenic and hepatic ultrasound and cytology in non-multicentric canine lymphoma}

\section{Nerschbach, N. Eberle, R. Mischke, I. Nolte, D. Simon Betz}

Small Animal Hospital, University of Veterinary Medicine, Hannover, Germany

Aim: In order to determine the extent of disease and clinical stage defined staging examinations are recommended. The aim of this retrospective study was to compare conventional staging (physical examination, complete blood count and chemistry, thoracic and abdominal radiographs and bone marrow examination) with extended evaluation including ultrasound and cytologic examination of liver and spleen in canine non-multicentric lymphoma. Methods: Medical records of dogs with cytologically or histologically diagnosed intestinal, mediastinal and extranodal lymphoma were reviewed. Inclusion criteria were ultrasound and cytological examination of spleen and liver in addition to conventional staging, as well as presence of information on epidemiological data and follow-up. Dogs were excluded if they had received cytotoxic or glucocorticoid treatment prior to diagnosis. Results: 43 dogs with intestinal (20/43), mediastinal (11/43) and extranodal (12/43) lymphoma were included into the study. Involvement of the spleen and liver in the intestinal group based on radiographs, ultrasound and cyto- logy amounted to $45 \%$ and $50 \%, 20 \%$ and $35 \%$, and $50 \%$ and $45 \%$, respectively. In the extranodal group, involvement of spleen and liver was as follows: based on radiographs $66 \%$ and $33 \%$, sonographic examination $58 \%$ and $42 \%$, and cytologic examination $42 \%$ and $75 \%$. In the mediastinal group, involvement of spleen and liver according to radiology, ultrasound and cytology amounted to $36 \%$ and $27 \%, 55 \%$ and $27 \%$, and $27 \%$ and $36 \%$, respectively. Conventional staging classified three patients in stage III and four patients in stage IV. Following ultrasound one patient was reclassified from stage III in stage IV. With cytologic examination of liver and spleen three patients were reclassified from stage IV to stage III. Three patients were classified in stage $\mathrm{V}$ based on evidence of lymphoma in the bone marrow. Conclusion: Ultrasonographic and cytologic examinations result in differing assessment of disease extent in canine non-multicentric lymphoma compared to traditional radiographic evaluation. Prognostic value of these diagnostic techniques however must be verified by future clinical studies.

\section{V10 Lomustine consolidation treatment following}

12-week combination chemotherapy: Efficacy and tolerability in 144 dogs with lymphoma

\section{S. Limmer, V. Nerschbach, N. Eberle, I. Nolte, D. Simon Betz}

Small Animal Hospital, University of Veterinary Medicine, Hannover, Germany

Aim: High-grade lymphoma in dogs is a chemoresponsive disease with remission rates exceeding $80 \%$ with combination chemotherapy. Recent trials aim at optimizing relapse-free interval and survival time. The aim of this prospective study was to evaluate efficacy and toxicity of a short-term chemotherapy protocol complemented by lomustine consolidation in dogs with lymphoma. Methods: Prospective clinical study treating dogs with a 12-week maintenance-free chemotherapy protocol combining L-asparaginase, vincristine, cyclophosphamide, doxorubicine and prednisolone followed by three cycles of lomustine. Inclusion criteria were cytologically or histologically diagnosed high-grade lymphoma and complete staging procedures. Dogs were excluded if they had received cytotoxic treatment prior to presentation. Results: 144 dogs with cytologically or histologically confirmed diagnosis of lymphoma entered the study. Lymphoma types included multicentric lymphoma: $\mathrm{n}=123$, alimentary lymphoma: $\mathrm{n}=13$, atypical lymphoma: $\mathrm{n}=7$, mediastinal lymphoma: $\mathrm{n}=1$. Overall response rate was $83 \%$, complete remission (CR) was achieved in $104(72 \%)$ and partial remission (PR) in $16(11 \%)$ dogs. Median duration of first CR amounted to $260 \mathrm{~d}$ (range, 9-2041 d), PR ranged from 6-1164 d (median $131 \mathrm{~d}$ ). Median survival in dogs with CR amounted to $334 \mathrm{~d}$ (range, 25-2046 d), overall median survival time was $252 \mathrm{~d}$ (range, 4-2046 d). In dogs with multicentric lymphoma $(\mathrm{n}=123)$, CR rate was $80 \%$, median CR duration, median overall survival, and median survival in CR dogs amounted to $260 \mathrm{~d}, 289 \mathrm{~d}$, and 344d, respectively. Neutropenic events were observed in 85 dogs (grade 1: $45 \%$, grade 2: $30 \%$ ). Thrombocytopenic and anemic episodes were recorded in 69 dogs (grade 1: 63\%) and 124 dogs (grade 1: 88\%), respectively. Gastrointestinal toxicosis included anorexia (grade 1: 49\%), diarrhea (grade 1: $71 \%$ ), and vomiting (grade 1: 73\%). Conclusion: Short-term chemotherapy followed by lomustine consolidation leads to satisfactory remission and survival time with acceptable toxicosis. Comparative studies must be performed to verify whether this regime bears an amelioration of outcome. 
V11 Tumorspezifische microRNA-Expressionsmuster im kaninen intestinalen T-Zell-Lymphom und Untersuchungen zur microRNA-Funktion in einer T-Zell-Lymphom-Linie

\section{Joos ${ }^{1}$, M. Leipig-Rudolph², K. Weber}

${ }^{1}$ Medizinische Kleintierklinik, Ludwig-Maximilians-Universität, München; ${ }^{2}$ Fachpraxis für Tierpathologie Bomhard/Pfleghaar, München

Einleitung: Kanine intestinale Lymphome sind histopathologisch schwierig von lymphoproliferativen Enteritiden zu unterscheiden. Lymphomspezifische microRNA-Expressions-muster könnten hilfreich zur diagnostischen Einordnung sein. Untersuchungen zur microRNA-Funktion in Lymphomzellen können Erkenntnisse zur Tumorpathogenese liefern. Studienziel war der Vergleich des microRNA-Expressionsmusters von intestinalen T-ZellLymphomen, lymphoproliferativen Enteritiden und gesundem Darm. Auffällig verändert exprimierte microRNAs wurden auf potenzielle Regulationsmechanismen für die Zellvermehrung in der kaninen T-Zell-Lymphom-Linie CL-1 untersucht. Material und Methoden: Je acht T-Zell-Lymphome, lymphoproliferative Enteritiden sowie gesundes Darmgewebe wurden untersucht (formalinfixiertes Gewebe in Paraffinblöcken). Die GesamtRNA wurde extrahiert und die microRNAs revers transkribiert. Für zwei Proben pro Gruppe wurde die Expression 192 verschiedener microRNAs auf PCR-Array-Platten untersucht. Zwölf in der Lymphomgruppe auffällig verändert exprimierte microRNAs wurden selektiert. Mittels einzelner qPCR-Assays wurde deren Expression in allen 24 Proben untersucht. Fünf dieser microRNAs wurden als microRNA-Analoga oder -Inhibitoren in die T-Zell-Lymphom-Linie CL-1 transfiziert und die Zellviabilität und -toxizität sowie die Expression möglicher Ziel-mRNAs 48 Stunden nach der Transfektion gemessen. Ergebnisse: Intestinale T-Zell-Lymphome zeigen ein microRNA-Expressionsmuster, das sie von gesundem Darmgewebe und von lymphoproliferativen Enteritiden unterscheidet. Besonders stark überexprimiert sind microRNAs des miR-106 363 Clusters (miR-18b, miR-20b, miR-363), stark herunterreguliert sind die Tumorsuppressor-miRNAs miR-192 und miR-203. Die Transfektion dieser microRNAs in CL-1-Zellen beeinflusst deren Proliferation und die Expression von Zellzyklusgenen. Schlussfolgerung: Die untersuchten microRNAs könnten zur Diagnostik eingesetzt werden und spielen eine potenzielle Rolle in der Pathogenese des T-Zell-Lymphoms.

\section{V12 Copy number variations and feline mammary cancer} survival: a multivariable prognostic study

\section{J. L. Granados-Soler ${ }^{1}$, J. Junginger ${ }^{2}$, M. Hewicker-Trautwein'2, J. Beck ${ }^{3}$,} B. Brenig ${ }^{4}$, J. T. Schille ${ }^{1}$, D. Betz ${ }^{1}$, H. Murua-Escobar ${ }^{5}$, I. Nolte ${ }^{1}$

${ }^{1}$ Small Animal Clinic, University of Veterinary Medicine Hannover, Foundation, Hannover, Germany; ${ }^{2}$ Institute of Pathology, University of Veterinary Medicine Hannover, Foundation, Hannover, Germany; ${ }^{3}$ Chronix Biomedical, Göttingen, Germany; ${ }^{4}$ Institute of Veterinary Medicine, University of Göttingen, Göttingen, Germany; ${ }^{5}$ Department of Hematology, Oncology and Palliative Medicine, University of Rostock, Rostock, Germany

Introduction: Feline mammary carcinomas (FMCs) are characterized by early metastasis. As the disease free survival (DFS) and overall survival (OS) are short, prognostic determination is crucial to guide treatment. Copy number variations (CNVs) are used to identify genomic regions involved in cancer development and susceptibility, however little is known about their prognostic potential. The aim of this study was to determine the prognostic value of CNVs analysis in FMCs. Methods: Thirty-three female cats with FMCs were followed up for a 2-year post-operative period. CNVs analysis on DNA isolated from paraffin-embedded and frozen tissue neoplastic samples was performed. Tumors were grouped based on biological behavior and morphology in two categories: tubulopapillary carcinomas (TC), and solid carcinomas and comedocarcinomas (SC). Kaplan-Meier curves and a multivariate analysis were applied to evaluate the influence of CNVs and clinical, epidemiological and histological variables on DFS and OS. Results: OS was negatively influenced by CNVs. Chromosomal gains and losses were independently associated with poor OS. DFS was negatively influenced by chromosomal gains. A higher amount of CNVs was associated with the SC category; cats in this group had lower DFS and OS than those in the TC category. In univariate analysis, CNVs, chromosomal gains and losses, clinical staging, and histological malignancy grade negatively influenced OS and DFS. In multivariate analysis, CNVs, chromosomal gains, and histological malignancy grade remained associated with poor OS. Conclusion: These data suggest an association between CNVs and poor OS, especially in those patients affected by solid carcinomas and comedocarcinomas.

\section{V13 Evaluation von synergistischen Effekten von Dichlor-} essigsäure und Azacitidin auf kanine und humane epitheliale Tumorzelllinien der Prostata

\section{T. Harting ${ }^{1,2}$, K. Kalies ${ }^{1}$, M. Stubbendorf ${ }^{3}$, H. Murua Escobar ${ }^{1,2}$, I. Nolte ${ }^{1}$}

${ }^{1}$ Klinik für Kleintiere, Stiftung Tierärztliche Hochschule Hannover, Hannover, ${ }^{2}$ Klinik für Hämatologie, Onkologie und Palliativmedizin, Universitätsmedizin Rostock, Rostock, ${ }^{3}$ Evotec AG, Hamburg

Einleitung: In der Kleintieronkologie sind die erzielten Therapieresultate insbesondere von metastasierten Tumoren nach wie vor unbefriedigend. Dichloressigsäure (DCA) steht im Interessenfokus der Forschung, lässt sich jedoch aufgrund seiner in hohen Dosen auftretenden Toxizität bisher nicht systemisch anwenden. Die Kombination von verschiedenen Substanzen bietet Möglichkeiten der besseren Effizienz, weshalb in dieser Studie die synergistischen Effekte on DCA und Azacitidin im Vergleich zu einer Monoapplikation evaluiert wurden. Material und Methoden: Verwendung fanden kanine und humane Zelllinien, die aus Prostataadenokarzinomen etabliert wurden. Nach Evaluierung der inhibitorischen Eigenschaften der Monosubstanzen mittels metabolischer Aktivität (MTT-Test) wurden die Zellen über 120 Stunden mit 5 mM DCA und/oder $2 \mu \mathrm{M}$ Azacitidin kultiviert. Neben der Zellzahl (Cellcounter) sowie der Apoptoserate (Durchflusszytometer) wurden die morphologischen Veränderungen der Zellen im Live Cell Imaging beobachtet. Der Einfluss von Azacitidin auf die Methylierung des DCA-Transporters wurde im Western Blot evaluiert. Ergebnisse: Im Vergleich zu der unbehandelten sowie der mit Monoapplikation behandelten Kontrolle konnte gezeigt werden, dass mit DCA/Azacitidin behandelte Zellen in ihrer Zellzahl signifikant reduziert werden. Die Reduktion beruht auf einer verminderten Proliferationsrate, unterstützt durch die verminderte metabolische Aktivität, die Apoptose hingegen wird nicht beeinflusst. Ein Einfluss von Azacitidin auf den DCA-Transporter konnte nicht nachgewiesen werden. Schlussfolgerung: Der synergistische Effekt von DCA und Azacitidin ist im Vergleich zu seiner entsprechenden Monoapplikation signifikant. Die hier identifizierte erforderliche DCA-Konzentration ist jedoch in vivo nicht verträglich. Weiterführende Untersuchungen, die eine potenzielle Applikation von DCA in in vivo relevanten Konzentrationen evaluieren, sind vorgesehen.

\section{V14 Charakterisierung der Chemosensitivität von Zelllinien urogenitaler Karzinome des Rüden}

E.-M. Packeiser ${ }^{1,2}$, H. Thiemeyer ${ }^{1,2}$, A. Mohr ${ }^{1}$, M. Hewicker-Trautwein ${ }^{3}$, H. Murua Escobar ${ }^{1,2}$, I. Nolte ${ }^{1}$

${ }^{1}$ Klinik für Kleintiere, Stiftung Tierärztliche Hochschule Hannover; ${ }^{2}$ Institut für Hämatologie, Universitätsmedizin Rostock; ${ }^{3}$ Institut für Pathologie, Stiftung Tierärtliche Hochschule Hannover

Einleitung: Das kanine Prostatakarzinom (PC) ist eine hoch aggressive Tumorerkrankung, gegen die es bisher keine zufriedenstellende Therapie gibt. Oft ist eine klare Differenzierung vom Übergangszellkarzinom (TCC) der 
Harnblase schwierig. Gut charakterisierte Zelllinien sind für präklinische Wirksamkeitsstudien geeignete Modellsysteme. Hierfür stehen derzeit wenige kanine PC- und TCC-Linien zur Verfügung. Ziel ist daher, Zelllinien zu finden, an denen präklinisch die Chemosensitivität untersucht werden kann. Der Fokus liegt hier auf der differenzierten Wirkung der Chemotherapeutika auf PC, TCC und Metastasen. Methoden: Selbst etablierte Zelllinien aus sechs kaninen urogenitalen Karzinomen und zwei Metastasen wurden hinsichtlich Wachstum und Morphologie charakterisiert. Der epitheliale Charakter wurde immunzytochemisch belegt. Vergleichend wurde die bereits charakterisierte kanine PC-Linie TihoDProAdcarc1258 betrachtet. Nach Inkubation mit Doxorubicin und Carboplatin wurden Stoffwechselaktivität, Zellzahl und Apoptoserate gemessen. Ergebnisse: Die Zelllinien wiesen Verdopplungszeiten zwischen 20 und 39 Stunden auf. Der epitheliale Charakter wurde durch die Zytokeratinexpression bestätigt. Die histologische Untersuchung der Ursprungsgewebe der Zelllinien ergab vier PC, zwei TCC und zwei PC-Metastasen. Für eine weitere Linie lag die zytologische Diagnose TCC vor. Carboplatin hemmte die Stoffwechselaktivität aller Linien in therapeutisch erreichbaren Konzentrationen. Sechs Zelllinien reagierten auf Doxorubicin mit verringertem Stoffwechsel, erhöhter Apoptoserate und verringerter Zellzahl. Eine PC-Linie und beide Metastasenlinien wiesen nach Doxorubicinbehandlung erniedrigte Zellzahlen auf, jedoch keine deutliche Stoffwechselhemmung. Schlussfolgerung: Doxorubicin und Carboplatin erwiesen sich in dieser Studie gegen urogenitale Karzinome des Rüden wirksam. Die Zelllinien können nun als stabile, reproduzierbare In-vitro-Modelle genutzt werden, um weitere potenzielle therapeutische Konzepte prä-in-vivo zu evaluieren.

\section{V15 Charakterisierung der zellulären Effekte des Aminoisochinolins FX-9 auf kanine und humane Prostatakarzinomzelllinien}

\section{J.T. Schille ${ }^{1,2}$, X. Wu ${ }^{3}$, L. Wiesner ${ }^{1}$, C. Roolf ${ }^{2}$, M. Beller ${ }^{3}$, C. Junghan $\beta^{2}$, I. Nolte ${ }^{1}, \mathrm{H}$. Murua Escobar ${ }^{2}$}

${ }^{1}$ Klinik für Kleintiere, Stiftung Tierärztliche Hochschule Hannover, Hannover; ${ }^{2}$ Klinik für Hämatologie, Onkologie und Palliativmedizin, Universitätsmedizin Rostock, Rostock; ${ }^{3}$ Leibniz-Institut für Katalyse e. V., Universität Rostock, Rostock Einleitung: Tumoren der Prostata des Hundes sind meist bösartig und neigen zur Metastasierung. Aufgrund der späten Diagnose beträgt die durchschnittliche Überlebensdauer weniger als 12 Monate; die zurzeit verfügbaren Therapien sind ungenügend. Neben dem Menschen sind Hunde die einzigen Säugetiere, die spontan Prostatakarzinome (PK) mit relevanter Inzidenz entwickeln. Der Hund wird dadurch auch zu einem immer wichtigeren Modell. Aufgrund mangelnder Therapiemöglichkeiten sind die Identifizierung und Evaluierung weiterer Behandlungsoptionen für beide Spezies von wesentlicher Bedeutung. Ziel dieser Studie war zu untersuchen, welche zellulären Effekte das Aminoisochinolin FX-9 auf kanine und humane PKZelllinien hat und ob es dadurch als Chemotherapeutikum zur Behandlung von PK eingesetzt werden könnte. Material und Methoden: Anhand je zwei kaniner und humaner PK-Zelllinien wurden Life Cell Imaging, morphologische Charakterisierung mittels Pappenheim-Färbung, MTS-Assay zur Bestimmung der metabolischen Aktivität, Zellzahl- sowie ApoptoseAnalysen mit steigenden Konzentrationen und Inkubationszeiten von FX-9 durchgeführt. Ergebnisse: Es konnte festgestellt werden, dass FX-9 einen Effekt auf alle untersuchten Zelllinien beider Spezies im Vergleich zu unbehandelten Kontrollen hat. Inkubation mit FX-9 führte zu morphologischen Veränderungen der behandelten Zellen, verringerte signifikant die metabolische Aktivität und Zellzahl und erhöhte den Anteil apoptotischer Zellen. Die Wirksamkeit von FX-9 war dabei zwischen den kaninen und humanen Zellen vergleichbar. Schlussfolgerung: Die gewonnenen Ergebnisse stellen eine vielversprechende Grundlage für FX-9 als potenzielles Chemothera- peutikum zur Behandlung von PK dar. Weiterführende molekulare Untersuchungen bezüglich des Wirkmechanismus von FX-9 können zeigen, ob sich Hunde als Modellorganismen für FX-9-Studien eignen.

\section{V16 Effects of endotoxin on thrombelastography including velocity curve in horses and ponies}

A. Gläsel ${ }^{1}$, E. Hübers ${ }^{1}$, C. Schedlbauer ${ }^{2}$, K. Roscher ${ }^{3}$, N. Bauer ${ }^{1}$, A. Moritz ${ }^{1}$

${ }^{1}$ Clinic for Small Animals, Justus-Liebig-University, Giessen, Germany; ${ }^{2}$ Institute of Animal Nutrition, Faculty of Veterinary Medicine, University of Leipzig, Germany; ${ }^{3}$ Equine Clinic, Internal Medicine, Justus Liebig University, Giessen, Germany

Background: Recently, the thrombelastography (TEG) velocity curve, the 1st mathematical derivative of the TEG tracing, has gained importance in people as a more sensitive coagulation test than conventional TEG. Coagulation activation decreases SP, R, K, TMRTG and increases $\alpha, M A, G, T G$, MRTG and L. In this study, we evaluated the influence of endotoxin (lipopolysaccharide, LPS) on TEG in horses and ponies. Impact of breed (horse vs pony) and laparotomic vs transcutaneous biopsy was investigated. Methods: Citrated whole blood samples were drawn from the jugular vein of healthy horses $(\mathrm{n}=15)$ and ponies $(\mathrm{n}=14)$ before $(\mathrm{t} 0)$ and $6(\mathrm{t} 1), 12(\mathrm{t} 2)$, 24 (t3) hours after infusion of $10 \mathrm{ng} / \mathrm{kg}$ LPS (Escherichia coli O55:B5). In ten horses and nine ponies, surgical liver samples (OP group) were taken 17 hours later. In the remaining animals (biopsy group), transcutaneous sampling was performed. One to three days prior to LPS challenge, animals in the OP group were transported to the Large Animal Clinic for Surgery, Leipzig University. Blood samples rested at room temperature for 1 hour before TEG (TEG 5000). TEG analysis was started after recalcification and kaolin activation. TEG variables SP, R, K, $\alpha, M A, G$ and velocity curve variables TG, TMRTG, MRTG and L were investigated. Results: At t0, the OP group had significantly shorter SP, R, K and higher TG compared to the biopsy group. In the biopsy group, $\mathrm{R}, \mathrm{K}$ and $\mathrm{SP}$ decreased significantly at $\mathrm{t} 1$ and $\mathrm{t} 2$. $\mathrm{K}$ was still significantly decreased at $\mathrm{t} 3$ and $\alpha$ significantly increased at $\mathrm{t} 1$ and $\mathrm{t} 3$. The OP group showed a significant reduction of $\mathrm{G}$ and $\mathrm{TG}$ at $\mathrm{t} 1$ followed by an increase from $t 1$ to $t 3$. Compared to horses, ponies had significantly shorter $\mathrm{K}$ at $\mathrm{t} 0$ and higher $\alpha, \mathrm{G}, \mathrm{TG}$ and $\mathrm{L}$ at $\mathrm{t} 0$, $\mathrm{t} 1$. Conclusion: LPS, in the dosage used, induces a mild coagulation activation of questionable clinical relevance. At baseline, ponies have "hypercoagulable" TEGs compared to horses, indicating that breed specific reference intervals should be established in future.

\section{V17 Einfluss einer Endotoxingabe auf die Thrombozyten- funktion bei klinisch unauffälligen erwachsenen Pferden und Ponys}

\section{E. Hübers' ${ }^{1}$, A. Moritz ${ }^{1}$, A.Gläsel' ${ }^{1}$, I. Vervuert'², D. Blaue², J. Starzoneck², K. Roscher ${ }^{1}$ \\ ${ }^{1}$ Klinikum Veterinärmedizin, Justus-Liebig-Universität Gießen, ${ }^{2}$ Institut für Tier- ernährung, Universität Leipzig}

Hintergrund: Beim Menschen unterstützen aktivierte Thrombozyten proinflammatorische Wirkmechanismen und tragen so zur Entstehung von Komplikationen im Rahmen einer Sepsis und Entwicklung eines Multiorganversagens bei. Ziel der Studie war, mittels intravenöser Gabe von Lipopolysacchariden (LPS, Endotoxin) den Einfluss einer induzierten systemischen Entzündungsreaktion auf die Thrombozytenfunktion bei klinisch unauffälligen erwachsenen Equiden zu überprüfen. Methode: Jeweils 16 Pferde und Ponys erhielten eine Infusion mit LPS (E. coli O55:B5, $10 \mathrm{ng} / \mathrm{kg}$ ). Vor, sowie 6, 12 und 24 Stunden nach der Endotoxingabe erfolgten Blutuntersuchungen. Der Schwerpunkt lag in der Untersuchung der Thrombozytenzahl (ADVIA 120) und der Thrombozytenfunktion mittels Impedanzaggrego-metrie (Multiplate ${ }^{\star}$ Analyzer). Beim Multiplate wurden die Agonisten ADP (ADPtest, 6,5 $\mu \mathrm{M}$ ), ADP und PGE2 (ADPtest HS, 
6,5 $\mu \mathrm{M} / 9,4 \mathrm{nM}$ ) und Arachidonsäure (ASPItest 0,75 mM) verwendet. Zudem wurde die Spontanaggregation ermittelt. Zum Zeitpunkt 22 Stunden erfolgte eine Entnahme von Lebergewebe mittels transkutaner Biopsie oder Laparotomie. Ergebnisse: Ein signifikanter klinisch nicht relevanter Einfluss von Zeit und Rasse auf die Thrombozytenzahl konnte berechnet werden. Die Thrombozytenfunktion zeigte in allen Fällen eine signifikante $\mathrm{Zu}$ nahme der Aggregation innerhalb von 12 Stunden nach Endotoxingabe. Zwischen Zeitpunkt 12 Stunden und 24 Stunden nahm die Thrombozytenaggregation ab. Hierbei hatte der Eingriff (Biopsie/Laparotomie) keinen Einfluss. Wenn auch der Verlauf gleich war, zeigten sich bei den absoluten Zahlen Unterschiede in der Rasse, wobei die Ponys eine deutlichere Zunahme der Aggregation aufwiesen. Schlussfolgerung: Die intravenöse Gabe von Endotoxin führt bei Equiden zu einer kurzzeitigen Zunahme der Thrombozytenaggregation. Ursächlich kann eine Anregung in vivo angenommen werden, die das prothrombotische Risiko erhöhen könnte. Die mutmaßliche Thrombozytenaktivierung könnte beim Pferd und verstärkt beim Pony proinflammatorische Wirkungen vergleichbar mit den Beobachtungen beim Menschen nach sich ziehen.

V18 Vergleich von drei verschiedenen Glukosedosierungen im oralen Glukosetoleranztest zur Diagnostik einer Insulindysregulation beim Pferd

\section{S. Schumacher ${ }^{1}$, T. Warnken ${ }^{1}$, P.S. Schmidt ${ }^{1}$, K. Huber ${ }^{2}$, K. Feige ${ }^{1}$}

${ }^{1}$ Klinik für Pferde, Stiftung Tierärztliche Hochschule Hannover, Hannover; ${ }^{2}$ Institut für Nutztierwissenschaften, Universität Hohenheim, Stuttgart

Studienziel: Eine Insulindysregulation (ID) ist neben Adipositas und einer Prädisposition für Hufrehe ein Hauptbestandteil des Equinen Metabolischen Syndroms (EMS). Zur Diagnostik der ID eignen sich orale Glukosetoleranztests (OGT). Insulindysregulierte Pferde reagieren auf die Stimulation mit einer überschießenden Hyperinsulinämie. Da Hufreheerkrankungen durch eine glukoseinduzierte Hyperinsulinämie verursacht werden können, war es Ziel dieser Studie zu untersuchen, ob die übliche Glukosedosierung für den OGT von $1 \mathrm{~g} / \mathrm{kg}$ Körpergewicht reduziert werden kann, ohne dass der Test an diagnostischer Aussagekraft verliert. Methoden: OGTs mit drei Glukosedosierungen (OGT: 1 g Glukose/kg; MOGT: 0,5 g Glukose/kg; LOGT: 0,25 g Glukose/kg) wurden an 18 Islandpferden mit unterschiedlichem Alter (19,65 \pm 4,69 Jahre), Gewicht $(403,22 \pm 43,52 \mathrm{~kg})$ und Body Condition Score $(5,95 \pm 1,07)$ durchgeführt. Nach 12-stündiger Nahrungskarenz und Applikation der jeweiligen Glukosemenge mittels Magensonde wurden über 4,5 Stunden Glukose- und Insulinkonzentrationen im Blut bestimmt. Ergebnisse: Die Glukose- und Insulinkonzentrationen zeigten dosisabhängige Variationen. Die Glukosekonzentration differierte signifikant zwischen LOGT und OGT ab 60 Minuten nach Applikation $(\mathrm{p}<0,001)$, während der Unterschied zwischen MOGT und OGT erst ab 90 Minuten signifikant wurde $(\mathrm{p}<0,0001)$. Der Insulinwert begann sich im LOGT ab 30 Minuten vom Wert des MOGT $(\mathrm{p}<0,05)$ und auch des OGT $(\mathrm{p}<0,01)$ signifikant zu unterscheiden, wohingegen zwischen MOGT und OGT erst ab dem Zeitpunkt 135 Minuten ein signifikanter $(\mathrm{p}<0,01)$ Unterschied bestand. Schlussfolgerung: Eine Glukosedosierung von $0,5 \mathrm{~g} / \mathrm{kg}$ kann für eine valide ID-Diagnostik als ausreichend angesehen werden. Neben der praxistauglicheren Durchführbarkeit des Tests lässt sich ein potenzielles Hufreherisiko damit deutlich minimieren.
V19 Beeinflusst die Applikation der Glukose via Nasenschlundsonde die klinisch relevanten Ergebnisse des oralen Glukosetoleranztests beim Pferd?

T. Warnken ${ }^{1}$, S. Schumacher ${ }^{1}$, F. Frers ${ }^{1}$, J. Delarocque ${ }^{1}$, K. Huber ${ }^{2}$, K. Feige ${ }^{1}$ ${ }^{1}$ Klinik für Pferde, Stiftung Tierärztliche Hochschule Hannover, Hannover; ${ }^{2}$ Institut für Nutztierwissenschaften, Universität Hohenheim, Stuttgart

Studienziel: Insulindysregulation (ID) ist eines der Hauptsymptome des Equinen Metabolischen Syndroms (EMS). Die Testprotokolle zur Diagnostik einer ID variieren von der Fütterung eines Glukosepulvers bis hin zur Verabreichung von Glukose mittels Magensonde im oralen Glukosetoleranztest (OGT). Bisher fehlen Untersuchungen zur stressinduzierten Aktivierung der Hypothalamus-Hypophysen-Nebennieren-Achse durch das Einführen der Magensonde und damit einer möglichen Beeinflussung der Testergebnisse. Methoden: Achtzehn Islandpferde unterschiedlichen Alters, Gewichts und Insulinstatus wurden in die Studie einbezogen. Die Tiere wurden einem OGT (Applikation von $1 \mathrm{~g} / \mathrm{kg}$ Körpergewicht Glukose in 21 Wasser gelöst per Magensonde) sowie einem Sham-OGT (SOGT; Applikation von 21 Wasser per Magensonde) unterzogen. Vor und im Anschluss an die Einführung der Magensonde wurden über 2 Stunden Blutproben entnommen und die Konzentrationen von Glukose, Insulin, Kortisol und ACTH bestimmt. Ergebnisse: Im OGT kam es zu einem zeitabhängigen Anstieg der Glukosekonzentration $(\mathrm{p}<0,0001)$ sowie der endogenen Insulinkonzentration ( $<<0,0001)$, während im SOGT die basalen Glukose- und Insulinkonzentrationen unbeeinflusst blieben und sich signifikant von denen des OGT unterschieden ( $\mathrm{p}<0,0001)$. ACTH und Kortisol zeigten im OGT und SOGT einen initialen Konzentrationsanstieg nach Einführung der Magensonde. Zum klinisch relevanten Probenentnahmezeitpunkt 120 Minuten nach Einführung der Sonde ergab sich jedoch kein statistisch signifikanter Unterschied zu den Basalwerten beider Parameter. Schlussfolgerung: Während die Insulin- und Glukosekonzentrationen im OGT den zu erwartenden Verlauf aufwiesen, war im SOGT keine Variation dieser feststellbar. Zusammenfassend kann die Applikation der Glukose mittels Magensonde im OGT durchgeführt werden, ohne die relevanten Testergebnisse für die Diagnostik einer ID durch Aktivierung der HypothalamusHypophysen-Nebennieren-Achse zu verfälschen.

\section{V20 Establishment of a competitive ELISA for detection of bovine IGF-binding protein-4}

\section{J. K. Benz ${ }^{1}$, K. Mense ${ }^{2}$, M. Jung ${ }^{2}$, M. Schmicke ${ }^{1}$}

${ }^{1}$ University of Veterinary Medicine Hannover, Clinic for Cattle, Endocrinology, Germany; ${ }^{2}$ Institute for the Reproduction of Farm Animals Schönow Inc., Bernau, Germany

Insulin-like growth factor binding protein-4 (IGFBP-4) is a member of the somatotropic axis which acts as a transporter protein for IGF and modulates its biological effect. Proteolytic cleavage of IGFBP-4 enables the contact of IGF-1 to IGF-receptor, mediating cell growth and inhibiting apoptosis. This is essential for fetal growth and development during gestation. Referring to previous studies, IGFBP4 concentration was higher from the day of insemination in cows developing embryonic or early fetal mortality. This leads to the assumption that IGFBP-4 concentrations may serve as a biomarker for detection of embryonic or early fetal mortality. The aim of this study was to enable the quantitative detection of IGFBP-4 in serum with a competitive enzyme-linked immunosorbent assay (ELISA). Therefore, recombinant bovine IGFBP-4 was commercially synthesized via transformation of E. coli which offers equal binding affinity like native IGFBP-4. Through biotinylisation of recombinant bovine IGFBP- 4 it is possible to determine the bovine IGFBP-4 concentration by applying a biotinylated probe to a sample and then detecting the bound probe with a labeled streptavidin. BSA and chicken serum serve as coating protein, preventing unspecific binding from 
IGFBP-4 to the wells. The lower detection limit was adjusted to $<17 \mathrm{ng} / \mathrm{ml}$ bovine IGFBP-4. Linearity of dilution was confirmed. The bovine IGFBP-4 ELISA enables a quick and reliable method for detection of IGFBP-4. This allows an easier monitoring of the respective IGFBP-4 concentration during pregnancy than the western blot ligand system used for IGFBP-4 quantification in previous studies. Comparison of pathological and physiological parameters leading to embryonic and early fetal mortality can be examined on a continuing basis.

\section{V21 Vergleich zweier Hämatologieautomaten in Bezug auf Gesamtleukozytenzahl, Hämoglobin und Hämatokrit bei Alpaka, Lama, Rind, Schaf, Schwein und Ziege}

\section{G. Wagener, T. Großmann, M. Stöter, M. Ganter}

Klinik für kleine Klauentiere, Stiftung Tierärztliche Hochschule Hannover

Ziel: Die automatisierte hämatologische Diagnostik ist in der Human- und Kleintiermedizin mittlerweile Standard. Im Nutztierbereich liefern Ergebnisse von Hämatologieautomaten jedoch mitunter falsche Ergebnisse, die sich auf eine stark abweichende Zellmorphologie einzelner Spezies zurückzuführen lassen. Besonders zu berücksichtigen ist dies bei Ziegen (relativ kleine Erythrozyten) und Neuweltkameliden (NWK; elliptoide Erythrozyten). Ziel dieser Untersuchung war, Messergebnisse verschiedener Hämatologieautomaten und manueller Methoden einander gegenüberzustellen. Blutproben von Alpakas, Lamas, Rindern, Schafen, Schweinen und Ziegen je Spezies wurden vergleichend analysiert. Methoden: Für den Routinebetrieb des Labors der Klinik für kleine Klauentiere stehen zwei Hämatologieautomaten zur Verfügung: das MEK-6450 Celltac Alpha (Nihon Kohden, Japan) (a) und das ProCyte Dx (IDEXX Laboratories, USA) (b). Als Probenmaterial dienten Vollblutproben (EDTA) aus Klinikbetrieb sowie Einsendungsbereich des Labors. Die Messungen erfolgten je nach Gerät mittels der Impedanzmethode (a) und der Laser Flow Cytometry (b). Bei NWK und Ziegen wurden die Parameter Gesamtleukozytenzahl, Hämatokrit und Hämoglobin zusätzlich mit manuellen Methoden (Leukozytenzählung mittels Neubauer-Kammer, Hämatokritzentrifuge und Hämoglobinbestimmung mittels Zyanlösung und Photometrie) bestimmt. Ergebnisse: Beim Vergleich der mittels beider Hämatologieautomaten und manuellen Proben bestimmten Parameter stellten sich zum Teil hochgradige Abweichungen bei Gesamtleukozytenzahl, Hämoglobin und Hämatokrit dar. Die stärksten Abweichungen ergaben sich beim Hämatokrit von NWK und Ziegen. Der automatisiert gemessene Hämatokrit von NWK wurde zum Teil zu niedrig, von Ziegen zum Teil sehr hoch bestimmt. Schlussfolgerung: Bei automatisiert erhobenen Befunden kommt es bei NWK und Ziegen mitunter zu hochgradigen Abweichungen. Insbesondere pathologische Befunde sollten bei allen Spezies mit manuellen Methoden überprüft werden. Bei Verlaufsuntersuchungen sollten die Messungen mit demselben Gerät erfolgen.

\section{V22 Jahreszeitliche und geschlechtsspezifische Verände-} rungen klinisch-chemischer Blutwerte Griechischer Landschildkröten (Testudo hermanni)

\footnotetext{
C. Leineweber ${ }^{1,4}$, A. C. Stöhr ${ }^{2}$, S. Öfner ${ }^{3}$, K. Mathes ${ }^{4}$, R. E. Marschang ${ }^{1}$ ${ }^{1}$ Laboklin GmbH \& Co. KG, Bad Kissingen; ${ }^{2}$ Louisianna State University, School of Veterinary Medicine, Zoological Medicine Service, Baton Rouge, LA, USA; ${ }^{3}$ Auffangstation für Reptilien, München e. V., München; ${ }^{4}$ Klinik für Heimtiere, Reptilien, Zier- und Wildvögel, Stiftung Tierärztliche Hochschule Hannover, Hannover Einleitung: Für die Interpretation der klinisch-chemischen Parameter im Blut von Schildkröten ist es entscheidend, diese mit spezifischen Referenzwerten zu vergleichen. In der Literatur finden sich zurzeit aber nur wenig spezies-, geschlechts- und auch jahreszeitlich spezifische Referenzwerte für
}

diese Tiere. Ziel dieser Studie war daher, für die am häufigsten in Deutschland gehaltene Landschildkrötenart Referenzwerte zu erstellen, die das Geschlecht und die Jahreszeit berücksichtigen. Material und Methoden: Blutproben von 270 griechischen Landschildkröten wurden von Mai 2016 bis Oktober 2017 gesammelt. Die klinisch-chemischen Parameter wurden aus Lithium-Heparin-Plasma mit dem Gerät cobas c701 analyzer (Roche Diagnostics, Mannheim) bestimmt. Ergebnisse: Die Resultate zeigen, dass es deutliche Unterschiede zwischen männlichen und weiblichen Tieren sowie starke jahreszeitliche Schwankungen gibt. Als Beispiel ist die Kalziumkonzentration zu nennen, die bei Weibchen höher ist als bei Männchen. Männliche Tiere zeigen höhere CK-Werte als weibliche, die im Verlauf des Jahres absinken. Die Harnsäure weist bei beiden Geschlechtern im Frühjahr höhere Werte auf als im Sommer. Diskussion: Die jahreszeitlichen und geschlechtsspezifischen Schwankungen der Laborwerte sind durch Reproduktion, Follikel- und Eianbildung bei weiblichen Tieren sowie gesteigerte Aktivität und Rangkämpfe bei Männchen begründet. Auch die jahreszeitlich schwankende Futterzusammensetzung trägt vermutlich zu saisonalen Variationen einiger Blutwerte bei. Ein Teil der nachgewiesenen Variationen wurde schon in früheren Studien festgestellt. Die Ergebnisse zeigen, dass es unerlässlich ist, die bestehenden Referenzwerte nach Jahreszeit und Geschlecht zu differenzieren, um Fehlinterpretationen und mögliche Fehldiagnosen zu vermeiden.

\section{V23 Einfluss der Separationsart auf die Plasmaqualität von Blutprodukten}

\section{E. Hindricks ${ }^{1}$, H. Lehmann ${ }^{2}$, E. Haßdenteufe ${ }^{2}$, N. Bauer ${ }^{1}$, A. Moritz ${ }^{1,2}$}

${ }^{1}$ Klinik für Kleintiere, klinische Pathophysiologie und klinische Laboratoriumsdiagnostik, Justus-Liebig-Universität Gießen; ${ }^{2}$ Klinik für Kleintiere, Innere Medizin, Justus-Liebig-Universität Gießen

Hintergrund: Der Einsatz von Blutprodukten erfolgt in der Veterinärmedizin immer häufiger, doch ist ihre Herstellung aufwendig und erfordert eine Vollblutzentrifuge. Das Ziel der Studie war die Evaluierung der Qualität von Blutprodukten, die mit einem neuartigen Hohlfaserfilter hergestellt wurden, im Vergleich zur Vollblutzentrifugation. Methoden: Von Februar bis Juni 2017 wurden 31 klinisch gesunde Hunde als Blutspender in die Studie eingeschlossen. Die Tiere wurden randomisiert den Gruppen Zentrifuge $(\mathrm{Z})$ $(\mathrm{n}=15)$ und Hohlfasersystem $(\mathrm{HF})(\mathrm{n}=16)$ zugeteilt. Ein Ausschluss erfolgte, wenn die Blutbeutel nicht vollständig befüllt wurden oder die Blutprodukte eine hochgradige Lipämie aufwiesen. Zur Überprüfung der Produktqualität erfolgte neben der Untersuchung von Gesamtprotein (TTP) und Albumin die Evaluation der Gerinnungsaktivität anhand von Gerinnungszeiten (aPTT, PT), Fibrinogen, Antithrombin III (ATIII) sowie der Faktoren V und VIII (FV, FVIII). Die Probenentnahme erfolgte vom Spender, Vollblutbeutel, Plasmabeutel, sowie vom Zitratplasma des Vollblutbeutels nach Lagerung bei Raumtemperatur für die Dauer der Blutproduktgewinnung. Ergebnisse: Das Plasma der Gruppe HF zeigte hochsignifikante Verlängerungen der PT $(\mathrm{p}<0,0001)$ und aPTT $(\mathrm{p}<0,0001)$ im Vergleich zur Gruppe Z. Des Weiteren fielen bei der Gruppe HF eine hochsignifikant geringere Fibrinogenkonzentration $(p<0,0001)$ und geringere Aktivitäten von FV ( $p=0,0019)$ und AT III ( $=0,0004)$ auf. Die TTP- und Albuminkonzentrationen im Plasma waren in Gruppe HF signifikant $(p=0,001)$ bzw. hochsignifikant $(\mathrm{p}=0,0001)$ niedriger als in Gruppe Z. Die Lagerung bei bei Raumtemperatur hatte keinen Einfluss. Schlussfolgerung: Die Produktqualität des Plasmas, das mit der Zentrifuge hergestellt wurde, war im Vergleich zum Hohlfasersystem besser. Die klinische Bedeutung der Reduktion einzelner Gerinnungsparameter ist trotz statistischer Signifikanzen unklar und in weiteren Studien zu evaluieren. Falls keine Zentrifuge zur Verfügung steht, stellt das Hohlfasersystem jedoch eine gute Alternative dar. 


\section{V24 Bedeutung der Retikulozytose bei der kaninen} und felinen Erythrozytose

M. Keßler', N. Bauer', J. Fuchs', D. Fleuth', E. Grußendorf'2, J. Lechner², F. Neuerer' ${ }^{2}$, R. Nickel ${ }^{2}$, T. Rieker ${ }^{2}$, C. Schwedes ${ }^{2}$, A. Moritz ${ }^{1}$

${ }^{1}$ Klinikum Veterinärmedizin, Klinische Pathophysiologie und klinische Laboratoriumsdiagnostik, Justus-Liebig-Universität, Gießen; ${ }^{2}$ verschiedene Tierkliniken

Ziel: Überprüfung, ob sich die Retikulozytenzahl als diagnostisches Kriterium für Rückschlüsse auf die Ätiologie einer Erythrozytose (E.) eignet; Evaluierung der Vorkommenshäufigkeit einer E. mit Retikulozytose. Material und Methoden: In einer retrospektiven Multicenterstudie wurden vollständige Erstmessungen der Analyzer ADVIA 2120 und ProCyte Dx der Jahre 2012-2017 ausgewertet. E. wurde definiert als Erhöhung von Erythrozytenzahl (RBC), Hämatokrit (Htk) und Hämoglobin (Hb). Tiere mit E. wurden retrospektiv in 10 ätiologische Gruppen eingeteilt (relative E., primäre E., hypoxisch kardial, hypoxisch pulmonal, hochgradige Adipositas/ Methämoglobinämie, tumorassoziiert, hormonell stimuliert, renal bedingt, physiologisch-rassebedingt, Ätiologie unklar). Ergebnis: 1,8\% (444/23909) der Hunde und 1,8\% (162/8818) der Katzen wiesen eine E. auf, die bei 18,9\% (84/444) bzw. 11,7\% (19/162) mit einer Retikulozytose verbunden war. Der Vergleich der Vorkommenshäufigkeit von E. mit bzw. ohne Retikulozytose zwischen den Gruppen innerhalb der Tierarten zeigte keinen signifikanten Unterschied. Die Retikulozytenzahl von Hunden mit physiologisch höherem Htk (Windhunde) lag signifikant niedriger als bei Hunden mit relativer oder kardial bedingter $\mathrm{E} .(\mathrm{p}=0,01)$. RBC, Htk und Hb waren bei Hunden mit relativer E. signifikant höher als bei Hunden mit pulmonal bedingter $\mathrm{E}$. $(\mathrm{p}<0,0001 ; \mathrm{p}=0,0013 ; \mathrm{p}=0,0002)$. Katzen mit hormonell stimulierter E. zeigten signifikant niedrigere Htk- und $\mathrm{Hb}$-Werte als solche mit relativer bzw. kardial bedingter E. ( $p=0,0048 ; p=0,013$ ). Insgesamt bestand eine große Überlappung zwischen den Gruppen. Schlussfolgerung: Eine E. tritt bei Hunden und Katzen recht selten und meist ohne Retikulozytose auf. Eine Retikulozytose kann bei Hunden Hinweise auf relative oder kardiale E. geben, stellt jedoch kein sicheres Unterscheidungskriterium dar.

\section{V25 Hippocampal expression of the CB1 receptor} in canine epilepsy

D. Kostic ${ }^{1}$, M. Nowakowska², J. Freundt Revilla', F. Attig ${ }^{3}$, F. Gualtieri², W. Baumgärtner ${ }^{3}$, H. Potschka ${ }^{2}$, A.Tipold ${ }^{1}$

${ }^{1}$ Small Animal Clinic and ${ }^{3}$ Department of Pathology, University of Veterinary Medicine Hannover; ${ }^{2}$ Institute of Pharmacology Toxicology and Pharmacy, Ludwig-Maximilians-University, Munich, Germany

Introduction: In epileptic dogs the endocannabinoid system could be involved in the pathomechanism through the cannabinoid receptor type 1 (CB1), controlling neuronal activity on the synaptic level by negative feedback mechanism. Endocannabinoids are elevated in cerebrospinal fluid, understanding their role could be crucial for development of new treatment strategies. The aim of the study was to describe CB1 receptors in epileptic patients and quantitatively compare them to healthy dogs. Materials and methods: CB1 receptor expression was evaluated by immunohistochemistry of the brains of seven control dogs, seven dogs with structural and five dogs with idiopathic epilepsy (CB1, Abcam ab23703, 1:200 IHC). Hippocampal density and intensity of $\mathrm{CB} 1$ receptor expression were analyzed in cornu ammonis (CA) 1, CA3, dentate gyrus (DG) and hilus using ImageJ software (U.S. National Institutes of Health, Bethesda, https:// imagej.nih.gov/ij/). Results: CB1 receptor expression was confirmed in the hippocampus of all dogs. In CA1 the area expressing CB1 receptor proved to be smaller in patients with idiopathic as compared to patients with structural epilepsy $(\mathrm{p}<0.0001)$ or healthy dogs $(\mathrm{p}<0.001)$. In the same region, intensity of the $\mathrm{CB} 1$ receptor staining was stronger in dogs with idio- pathic than structural epilepsy $(\mathrm{p}<0.001)$. Comparable statistically significant group differences with smaller area and higher intensity of CB1 receptor expression in idiopathic epilepsy dogs in comparison to structural epilepsy occurred in DG, CA3 and hilus. Conclusion: The results of the study give evidence for a downregulation of CB1 receptor expression in idiopathic canine epilepsy in sub-regions of the hippocampus. The disease seems to cause a redistribution of $\mathrm{CB} 1$ receptors proving that the endocannabinoid system is a major component of epileptogenesis.

\section{V26 Beschreibung und Vergleich der klinischen Charakteristika von Synkopen und epileptischen Anfällen bei Hunden \\ A. Leithner, A. Fischer und G. Wess \\ Medizinische Kleintierklinik, Ludwig-Maximilians-Universität München Abstract nicht verfügbar.}

V27 Messung von Liquor- und Serumkonzentrationen des Neutrophilen-Gelatinase-assoziierten Lipocalins und dessen Rolle bei immunmediierten Erkrankungen des Hundes

N. Meyerhoff, R. Carlson, A. Tipold

Klinik für Kleintiere, Tierärztliche Hochschule Hannover

Einleitung: Neutrophilen-Gelatinase-assoziiertes Lipocalin (NGAL) wird durch Granulozyten, Astrozyten, Endothel- und Epithelzellen produziert. Es ist Teil der Akute-Phase-Reaktion und spielt bei immunmediierten Erkrankungen des Zentralnervensystems (ZNS) eine Rolle. Hierbei gibt es sowohl Hinweise auf neuroprotektive als auch auf schädigende Funktionen durch Rekrutierung neutrophiler Granulozyten. Ziel und Methode: Ein ELISA-Kit zur Messung von NGAL-Konzentrationen wurde für die Anwendung an kaninem Liquor cerebrospinalis validiert. Es erfolgte ein Vergleich der NGAL-Konzentrationen in Liquor und Serum bei gesunden Hunden sowie Hunden mit entzündlichen oder anderen Erkrankungen des ZNS, um die Hypothese zu bestätigen, dass Hunde mit entzündlichen ZNSErkrankungen eine höhere NGAL-Konzentration im Liquor aufweisen. Mittels Receiver-Operating-Characteristics(ROC)-Kurven wurde geprüft, ob durch Messung von NGAL im Liquor Meningoenzephalitiden unbekannter Ätiologie (MUE) von intrakraniellen Neoplasien differenziert werden können. Ergebnis: Die NGAL-Konzentration war bei 29 Hunden mit akuter steroidresponsiver Meningitis-Arteriitis (SRMA) (Median: 2,8 ng/ml) und 13 Patienten mit MUE (Median: 1,79 ng/ml) signifikant höher $(\mathrm{p}<0,05)$ als bei Hunden mit SRMA in Remission $(\mathrm{n}=21$, Median: $0,3 \mathrm{ng} / \mathrm{ml})$, idiopathischer Epilepsie $(\mathrm{n}=21$, Median: $0,24 \mathrm{ng} / \mathrm{ml})$, Bandscheibenvorfall $(\mathrm{n}=22$, Median $0,28 \mathrm{ng} / \mathrm{ml})$ oder intrakranieller Neoplasie ( $\mathrm{n}=16$, Median: 0,33 ng/ml). Die NGAL-Konzentration im Liquor bei akuter SRMA lag signifikant höher als in der Kontrollgruppe ( $\mathrm{n}=7$, Median: 0,43 ng/ml). Zwischen NGAL-Konzentration im Liquor und Grad der Pleozytose zeigte sich eine positive Korrelation (Spearman; $r=0,6155$; $\mathrm{p}<0,0001$ ). Die Messung der NGAL-Konzentration im Liquor konnte zwischen MUE und intrakranieller Neoplasie differenzieren (Sensitivität: 87,5\%, Spezifität: 84,62\%). Schlussfolgerung: Die Ergebnisse weisen auf eine Funktion des Akute-Phase-Proteins NGAL bei immunmediierten Erkrankungen des ZNS und seine Rolle bei der Rekrutierung von Immunzellen hin. Eine Messung kann auch diagnostischen Zwecken dienen. 


\section{V28 Leptospiren-Infektion bei Hunden in Thailand}

K. Altheimer ${ }^{1}$, P. Jongwattanapisan², S. Luengyosluechakul2 ${ }^{2}$, R. Pusoonthornthum $^{2}$, N. Prapasarakul ${ }^{2}$, A. Kurilung' ${ }^{2}$, M. Goris ${ }^{3}$, K. Hartmann ${ }^{1}$ ${ }^{1}$ LMU München; ${ }^{2}$ Chulalongkorn University, Bangkok; ${ }^{3}$ Leptospirosis Reference Laboratory, Amsterdam

Hintergrund: Leptospirose ist eine weit verbreitete Zoonose und gilt als „Re-emerging Disease“. Die humane Leptospirose ist in Thailand häufig, die Ausscheidungsprävalenz bei Hunden aber unbekannt. Ziel der Studie war, die Prävalenz der renalen Leptospirenausscheidung und die Antikörperprävalenz mittels Mikroagglutinationstest (MAT) bei Hunden in Thailand zu bestimmen. Material und Methoden: In Nord-, Nordost- und Zentralthailand wurden 273 Straßenhunde $(\mathrm{n}=119)$ und Haushunde $(\mathrm{n}=154)$ aus ländlichen ( $\mathrm{n}=139)$ und urbanen $(\mathrm{n}=134)$ Gegenden zufällig ausgewählt. Hunde, die in den 4 Wochen vor der Probenentnahme Antibiotika erhalten hatten, wurden ausgeschlossen. Keiner der Hunde war gegen Leptospirose geimpft. Die Urinproben wurden mit einer für das Leptospirengen lipL32 spezifischen Real-Time-PCR untersucht und in Ellinghausen-McCulloughJohnson-Harris-Medium für 6 Monate kultiviert. Antikörper gegen $24 \mathrm{Se}$ rovare (Australis, Bratislava, Autumnalis, Rachmati, Ballum, Bataviae, Paidjan, Broomi, Canicola, Anhoa, Celledoni, Cynopteri, Djasiman, Grippotyphosa, Copenhageni, Icterohaemorrhagiae, Coxi, Khorat, Pomona, Pyrogenes, Haemolytica, Saxkoebing, Sejroe, Patoc) aus 15 Serogruppen wurden mittels MAT bestimmt. Ergebnisse: Urinproben von 12/273 Hunden (4,4\%; 95\%-Konfidenzintervall [KI]: 2,0-6,8\%) waren PCR-positiv. Bei 1/12 PCRpositiven Hunden konnten Leptospiren aus dem Urin kultiviert werden. Leptospirenantikörper wurden bei 33/273 Hunden (12,1\%; 95\%-KI: 8,2-16,0\%) gegen 19 verschiedene Serovare (Australis, Bratislava, Rachmati, Ballum, Bataviae, Paidjan, Broomi, Canicola, Anhoa, Grippotyphosa, Copenhageni, Icterohaemorrhagiae, Coxi, Khorat, Pyrogenes, Haemolytica, Saxkoebing, Sejroe, Patoc) gefunden. Schlussfolgerung: Die LeptospirenAusscheidungsprävalenz bei Hunden in Thailand ist mit denen in Europa und USA vergleichbar. Daher sollten Impfungen, die die Ausscheidung verhindern, vermehrt eingesetzt werden.

V29 Sensitivität einer diskriminierenden Polymeraseketten-Reaktion zum Nachweis mutierter feliner Coronaviren in verschiedenen Körpergeweben und -flüssigkeiten bei Katzen mit feliner infektiöser Peritonitis

L. Emmler ${ }^{1}$, S. Felten' ${ }^{1}$, K. Matiasek², H.-J. Balzer ${ }^{3}$, N. Pantchev ${ }^{3}$, C. Leutenegger ${ }^{4}$, K. Hartmann ${ }^{1}$

${ }^{1}$ Medizinische Kleintierklinik, Ludwig-Maximilians-Universität München; ${ }^{2}$ Institut für Tierpathologie, Ludwig-Maximilians-Universität München; ${ }^{3}$ IDEXX Vet Med Labor GmbH, Ludwigsburg; " 4 DEXX Laboratories, Inc., West Sacramento CA, USA Abstract nicht verfügbar.

\section{V30 Untersuchung zur Prävalenz von felinen Coronaviren in Katzenzuchten}

\section{U. Klein, M. Bergmann, S. Unterer, K. Hartmann}

Medizinische Kleintierklinik, Ludwig-Maximilians-Universität München

Einleitung: Feline Coronaviren (FCoV) kommen in Mehrkatzenhaushalten häufig vor. Die genaue Prävalenz von FCoV in Katzenzuchten in Deutschland und Faktoren mit Einfluss auf die Prävalenz sind jedoch nicht bekannt. Ziel der Studie war, die Prävalenz von FCoV in deutschen Katzenzuchten und Risikofaktoren für eine FCoV-Infektion zu untersuchen. Material und Methoden: Von 226 Katzen aus Katzenzuchten in ganz Deutschland wurden vier Kotproben (gesammelt im Abstand von jeweils einer Woche) mittels Polymerase-Kettenreaktion (PCR) auf FCoV untersucht. Mittels eines Fragebogens wurden Faktoren bezüglich Haltung und Zuchtmanagement der Katzen ermittelt. Der Kot wurde außerdem auf andere Durchfallerreger untersucht (felines Parvovirus, Giardia spp., Tritrichomonas foetus, Toxoplasma gondii, Clostridium perfringens a-Toxin und Enterotoxin, Salmonella spp., Cryptosporidia spp., Campylobacter jejuni und Campylobacter coli mittels PCR sowie auf parasitäre Entwicklungsstadien mittels Flotation). Eine Korrelation zwischen FCoV-Nachweis und Risikofaktoren wurde mittels Fisher's Exact Test ermittelt. Ergebnisse: Die Prävalenz von FCoV lag bei $76,6 \%$ (173/226). Einen signifikanten Einfluss auf die Infektion mit FCoV hatten eine fehlende Endoparasitenbehandlung durch die Züchter ( $\mathrm{p}=$ 0,010; Odds Ratio [OR]: 3,700; 95\%-Konfidenzintervall [95\%-KI]: $1,258-10,880)$, Koinfektionen mit anderen Durchfallerregern ( $p=0,025$; OR: 2,800; 95\%-KI: 1,137-7,080) und der Kontakt zu bestandsfremden Katzen ( $\mathrm{p}=0,048$; OR: 2,351; $95 \%$-KI: 1,035-5,340). Andere Faktoren, wie die Anzahl der zusammen gehaltenen Katzen $(\mathrm{p}=0,421)$ und das Alter der Katzen $(\mathrm{p}=1,000)$ beeinflussten das Vorhandensein von FCoV-Infektionen nicht signifikant. Schlussfolgerung: Etwa drei Viertel aller Katzen in deutschen Katzenzuchten sind mit FCoV infiziert. Ein mangelhaftes Parasitenmanagement und Kontakt zu bestandsfremden Katzen sind wichtige prädisponierende Faktoren.

V31 Retrospektive Analyse von vektorübertragenen Infektionen bei Hunden nach Reisen in endemische Regionen (2007-2015)

\section{Schäfer ${ }^{1}$, M. Volkmann², R. Merle², B. Kohn ${ }^{1}$}

${ }^{1}$ Klinik für kleine Haustiere, Fachbereich Veterinärmedizin, Freie Universität Berlin; ${ }^{2}$ Institut für Veterinär-Epidemiologie und Biometrie, Freie Universität Berlin

Einleitung: Vektorübertragene Erkrankungen gewinnen in Deutschland durch klimatische Veränderungen, den vermehrten Import von Hunden aus dem Ausland, aber auch durch den zunehmenden Reiseverkehr an Bedeutung. Endemische Regionen für Erreger wie Leishmanien, Hepatozooen, Ehrlichien und Dirofilarien sind der Mittelmeerraum und Südosteuropa. Anaplasmen und Babesien verschiedener Spezies sind in ganz Europa verbreitet. Ziel der retrospektiven Studie war festzustellen, ob Hunde bei Reisen in endemische Regionen einem entsprechenden Infektionsrisiko ausgesetzt sind. Material und Methoden: Einbezogen wurden die Befunde der Erstuntersuchung von 227 Patienten der Kleintierklinik der FU Berlin zwischen 01/2007 und 12/2015, die reisebegleitend in endemischen Regionen waren (13 Länder am Mittelmeer, vier in Südosteuropa). Insgesamt wurden 1113 Untersuchungen bei Fremdlaboratorien beauftragt (579 direkte/534 indirekte Nachweisverfahren). Ergebnisse: Die positiven Befunde verteilten sich wie folgt: Anaplasma phagocytophilum 15/158 Hunde (9,5\%; PCR 5/149; IFAT 11/38), Ehrlichia canis 13/169 (7,7\%; PCR 2/45; IFAT 13/157), Leishmania infantum 9/195 (4,6\%; PCR 4/42; IFAT 7/181; ELISA 0/12), Babesia canis 8/176 (4,5\%; PCR 2/93; IFAT 4/118; ELISA 2/17), B. gibsoni 2/99 (2\%; PCR 2/90; IFAT 0/11). Auf Dirofilaria immitis (ELISA 0/79), Mikrofilarien (PCR 0/6), Hepatozoon canis (PCR 0/21) und Anaplasma platys (PCR 0/5) wurde kein Hund positiv getestet. Der Knott-Test war bei 0/47 Hunden positiv. Bei 6/227 Hunden (2,6\%) ließen sich Mischinfektionen nachweisen. Schlussfolgerung: 39/227 (17,2\%) der untersuchten Hunde waren für mindestens einen Erreger positiv. Eine Prophylaxe gegen erregerübertragende Vektoren ist bei Hunden, die sich in endemischen Regionen im In- und Ausland aufhalten, von großer Bedeutung. 


\section{V32 Leptospiren-Infektion bei Katzen in Thailand}

F. Sprißler ${ }^{1}$, P. Jongwattanapisan², S. Luengyosluechakul'2, R. Pusoonthornthum ${ }^{2}$, N. Prapasarakul ${ }^{3}$, A. Kurilung ${ }^{3}$, M. Goris ${ }^{4}$, A. Ahmed ${ }^{4}$, R. Dorsch ${ }^{1}$, K. Hartmann ${ }^{1}$

${ }^{1}$ Ludwig-Maximilians-Universität München; ${ }^{2}$ Department of Veterinary Medicine, Chulalongkorn University, Bangkok ; ${ }^{3}$ Veterinary Microbiology Department, Chulalongkorn University, Bangkok; ' ${ }^{4}$ eeptospirosis Reference Laboratory, Amsterdam

Hintergrund: Leptospirose ist in Thailand endemisch und tritt in den letzten Jahren bei Menschen und Tieren vermehrt auf. Es wurde gezeigt, dass Katzen pathogene Leptospira spp. mit dem Urin ausscheiden können, in Taiwan sogar mit einer Prävalenz von $67,8 \%$. Bisher gibt es keine Studien über Infektionen mit Leptospiren bei Katzen in Thailand. Ziel der Studie war, die Prävalenz der Ausscheidung pathogener Leptospiren im Urin und die Antikörperprävalenz bei Katzen zu bestimmen und Risikofaktoren zu analysieren. Material und Methoden: 260 Freigängerkatzen wurden prospektiv untersucht. Ihr Urin wurde mittels einer für das lipL32-Gen spezifischen Real-Time-PCR auf pathogene Leptospira spp. untersucht und in Ellinghausen-McCullough-Johnson-Harris-Medium für 6 Monate kultiviert.
Antikörpertiter gegen 24 Serovare (Australis, Bratislava, Autumnalis, Rachmati, Ballum, Bataviae, Paidjan, Broomi, Canicola, Anhoa, Celledoni, Cynopteri, Djasiman, Grippotyphosa, Copenhageni, Icterohaemorrhagiae, Coxi, Khorat, Pomona, Pyrogenes, Haemolytica, Saxkoebing, Sejroe, Patoc), die 16 Serogruppen angehören, wurden mittels Mikroagglutinationstest (MAT) bestimmt. Risikofaktoren wurden mittels Fisher's Exact Test evaluiert. Ergebnisse: Urinproben von 2/260 Katzen (0,8\%; 95\%-Konfidenzinterval (95\%-KI): 0-1,8\%) waren PCR-positiv, allerdings keine der 260 Urinkulturen. Leptospira-spp.-Antikörper wurden bei 14/260 Katzen (5,4\%; 95\%-KI: 2,6-8,1\%) mit Titern von 1:20-1:160 (Serovare: Autumnalis, Anhoa, Celledoni, Djasiman, Copenhageni, Icterohaemorrhagiae, Patoc) gefunden, davon bei 4/14 Katzen ausschließlich gegen ein saprophytäres Serovar (Patoc). Keiner der untersuchten Risikofaktoren war signifikant mit einer Leptospireninfektion assoziiert. Schlussfolgerung: Katzen in Thailand können pathogene Leptospira spp. mit dem Urin ausscheiden, wobei die Prävalenz niedriger ist als erwartet. Weitere Studien sind notwendig zur Beurteilung der Rolle von Katzen als Infektionsquelle.

\section{Meldung}

\section{VETIDATA}

VETIDATA stellt eine Informationsplattform zu Fragen in Bezug auf Arzneimittelanwendung, Toxikologie und Arzneimittelrecht dar. Umfassende Informationen wie aktuelle Rechtsvorschriften, Angaben zu Präparaten, Impfstoffen, Wirkstoffen und zur Rückstandsproblematik erhalten Sie über den Internetauftritt unter http://www.vetidata.de oder die bundeseinheitliche Servicerufnummer. Per Telefon, Fax oder E-Mail können auch individuelle Fragestellungen geklärt werden.
Der Zugriff auf die Webseite ist registrierten Nutzern vorbehalten. Unter „Registrierung" erstellen Sie Ihren persönlichen Zugang. Bei weiteren Besuchen der Webseite können Sie über "Login" mit Ihren Zugangsdaten auf die Inhalte von VETIDATA zugreifen.

Das Entgelt für den Zugriff per Internet beträgt derzeit $55,-€ / J a h r$ zzgl. der geltenden Mehrwertsteuer. Innerhalb einer Testphase von 4 Wochen nach der erstmaligen Registrierung können Nutzer den Vertrag kündigen, ohne dass weitere finanzielle Forderungen entstehen.

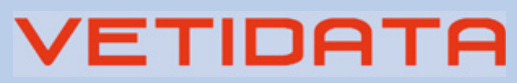

Veterinärmedizinischer Informationsdienst für Arzneimittelanwendung, Toxikologie und Arzneimittelrecht

An den Tierkliniken 39 04103 Leipzig http://www.vetidata.de E-Mail: info@vetidata.de Fax: 03 41-97 38439 Servicerufnummer für Anfragen: 01 80-500 9119 (0,14 €/Minute im Festnetz, max. 0,42 €/Minute aus Mobilfunknetzen), Montag-Freitag: 9:00-16:00 Uhr 